\title{
K.T.Zhumagulov ${ }^{1}$, Sadykova R.O. ${ }^{2}$
}

${ }^{I}$ Doctor of Historical Sciences, Professor of the Department of World History, historiography and source studies, Academician, Director of the Scientific-Research Center on World History Studies, Al-Farabi Kazakh National University e-mail: kalkaman.zhumagulov@kaznu.kz

${ }^{2}$ Candidate of historical sciences, Associate Professor of the Department of World History, historiography and source studies, Al-Farabi Kazakh National University e-mail: raikhan.sadykova@gmail.com

\section{ACTUAL ISSUES OF RESEARCH OF ATTILA'S INVASION OF NOTHERN ITALY}

\section{Abstract}

The purpose of this paper is to demonstrate the evolution of international relations in Europe in the middle of the $5^{\text {th }}$ century, which involved a struggle for hegemony between the Hunnish Empire ruled by Attila on the one hand and both of the Roman Empires - on the other hand. By the late spring of 452, Attila had gathered capable troops and went ahead with launching a new campaign into Italy, the heart of the Roman Empire. The Byzantine diplomacy managed to send Attila against the West and may have played its role in this. The Hun aristocracy and hordes are thought to spur their ruler into launching the campaign to capture new spoils of war too. At all events, it is necessary for us to objectively reconstruct the events of the Italian campaign.

Keywords: Attila, Italy campaign, The Hunnic Empire, Western Roman Empire, Eastern Roman Empire.

\section{К.Т. Жұмавұлов ${ }^{1}$, Р.О. Садық̧ова ${ }^{2}$}

${ }^{l}$ т.в.д., Дүние жүзі тарихы, тарихнама және деректану кафедрасының профессоры, академик, Дүниежүзі тарихын зерттеу бойынша Республикалық зылыми-зерттеу орталывының директоры, әл-Фараби ат. Қазақ ұлттық университеті e-mail: kalkaman.zhumagulov@kaznu.kz

${ }^{2}$ m.в.к., Дүние жүзі тарихы, тарихнама және деректану кафедрасының қауымдастырылван профессоры, әл-Фараби ат. Қазақ ұлттық университеті e-mail: raikhan.sadykova@gmail.com

\section{АТТИЛАНЫҢ СОЛТУСТІК ИТАЛИЯНЫ ЖАУЛАП АЛУЫНЫН ӨЗЕКТІ МӘСЕЛЕЛЕРІ}

\section{Аң̧датna}

Ұсынылған мақаланың мақсаты V-ші ғасырдың ортасындағы Еуропадағы халықаралық қатынастардың дамуын көрсету болып табылады. Осы кезеңнің басты оқиғасы бір жағынан Аттила бастаған Ғұн державасы мен екінші жағынан Рим империясы арасындағы үстемдік үшін күреске шоғырланды. 452-ші жылдың көктемінің соңында-ақ, ол әскнири қабілетті жасағын жинақтап, жаңа жорықты Рим империясының жүрегі - Италияға бағыттады. Мұндай шешімнің қабылдануына Аттиланың жасағын Римға бағыттай білген және осы арқылы өзінен қауіптіі алдын алған Византиялық дипломатияның әсері болғандығы даусыз. Ғұн ақсүйектері мен ордалары жаңа олжаға ие болу үшін өз әскери көшбасшысын Италияға қарсы жорықты ұйымдастыруға итермелеуінің Аттиланың шешім қабылдауына әсер еткені айқын. Осы тұрғыдан алғанда біз үшін Италияға қарсы жорықты объективті тұрғыда зерттеу қажеттілігі туындап отыр.

Кілт сөздер: Аттила, Италияға жорық, Ғұн империясы,Батыс Рим империясы, Шығыс Рим империясы.

$$
\text { Жумагулов К.T. }{ }^{1} \text {, Садыкова Р.О. }{ }^{2}
$$

${ }^{I}$ д.и.н., профессор кафедры всемирной истории, историографии и источниковедения, академик, директор РНИЦ по изучению Всемирной истории, КазНУ им. аль-Фараби 


\author{
e-mail: kalkaman.zhumagulov@kaznu.kz \\ ${ }^{2}$ к.и.н., и.о. ассоциированный профессор кафедры всемирной истории,историографии и \\ источниковедения, КазНУ им. аль-Фараби \\ e-mail: raikhan.sadykova@gmail.com
}

\title{
АКТУАЛЬНЫЕ ВОПРОСЫ ИЗУЧЕНИЯ ЗАВОЕВАНИЯ АТТИЛОЙ СЕВЕРНОЙ ИТАЛИИ
}

\section{Аннотация}

Целью настоящей статьи является показ сложной истории международных отношений в Европе в середине V в., основным содержанием которой является борьба за гегемонию между Гуннской державой Аттилы с одной стороны, и двумя Римскими империями - с другой. Уже к концу весны 452 г. он собрал боеспособное войско и приступил к организации нового похода и теперь уже ни куда-нибудь, а в сердце Римской империи - Италию. В таком исходе свою роль сыграла, по-видимому, и Византийская дипломатия, которая сумела направить Аттилу против Запада и тем самым отвести от себя нависшую угрозу. В такой же мере, думается, что и сама гуннская аристократия, и орды подталкивали своего властителя на организацию похода в целях захвата новой добычи. Как бы там ни было, нам необходимо объективно воссоздать события итальянского похода.

Ключевые слова: Аттила, поход в Италию, Гуннская империя, Западная Римская империя, Восточная Римская империя.

\section{Introduction}

Having sent a small force against the Eastern Empire, Attila led the main forces against Italy. Simultaneously, he may have hoped to destroy the army of Roman general Aetius, whom Attila hated especially after the Battle of the Catalaunian Fields, which was possible since it would have taken the Byzantine Empire some amount of time to come to the Western Empire's assistance. Perhaps he believed that once the Huns' horse cavalry had passed the River Po Aetius would have sued for peace. It is possible that Attila also expected the Roman Emperor Valentinian III to hasten to throw his general to the wolves to save his throne.

Attila's time left an indelible mark on the history of Eurasia, which has been not only preserved in historical works, chronicles and epic creations. We have also been able to establish that the great deeds of the Huns and their ruler were reflected at least in eighteen works of the German heroic epos and Scandinavian sagas.

At the same time, one might ask why so much attention is paid to the Huns in the scriptures and legends if they came to the West as conquerors. In our opinion, the answer may be as follows. Many European nations considered the Hun power as a counterbalance to the Roman Empire, as the savior from the Roman expansion. Thus, a number of Germanic tribes who were dependent on the Hunnish Empire participated in the wars against Rome.

By the middle of the fifth century, the relations between the Western Roman Empire and the Hunnish Empire had increasingly deteriorated. It became obvious that those forces were on the brink of a great confrontation. The events that took place in the mid-fifth century gave evidence of the military might of the Hunnish Empire.

Having accumulated and concentrated power, Attila, the ruler of the Huns, launched a military campaign against Western Europe, i.e. against the Western Roman Empire. The struggle against the Huns united the Roman Empire, the Visigoths and other unions of Celtic and Germanic tribes.

The rarest written sources for the period of late antiquity and the early Middle Ages have come to us in the original Latin, Greek, Early Germanic and Scandinavian languages. There is also evidence regarding the Turkic world and the Huns. In particular, these are the chronicles of Ammianus Marcellinus, Sidonius Apollinaris, Claudius Claudianus, Hidatii, Marcellinus Comes, Orosius, Jordanis, Priscus of Panitus, Prosper Tiro, Joahn Antioch, etc.

The documents and materials in scientific collections and museums of the Vatican, as well as the materials in the interiors of St. Peter's Basilica - the world's largest Catholic Church - are of particular value. There is papal correspondence, and also chronicles, eyewitness accounts of those years, exhibits that could shed much light on the nature of international relations during this tumultuous period in world history. One of the most important sources for reconstruction of the events of the second campaign of the Huns in Europe, which, unfortunately, have not been reflected in the works of Russian historians, is the 
documents and materials of the papal correspondence. First of all, they are the letters of Leo I the Great, Pope of Rome (440-461), which significantly clarify the course of events.

In the collection of rare literary monuments of the famous library of Georg-August University of Göttingen that is well-known throughout Europe one of the author of this article Prof. K. Zhumagulov found an interesting source that, at first glance, has nothing to do with the history of the Huns in Italy. It is a novella written by Valentinian III, the Roman Emperor. These important sources too were used on this article. In addition, we have extensively used the modern materials of archaeological excavations and interdisciplinary research, witnessing a high level of development of industry, trade, military art and other aspects of the social development of the Hun society.

Thus, our research methods are based on the use of rare written sources in Latin. The data of archeology, ethnology, historical linguistics and modern interdisciplinary research are made use of especially widely in our study.

\section{Attila's invasion to Italy: its development and consequences}

The greatest territorial expansion and the greatest power of the Hun Empire in the West was when the centre of their activities reached Pannonia under the leadership of Attila. Attila was a great statesman who did great deeds. He was a wise ruler, a skilled diplomat, and a fair judge. With good reason he should be considered a prominent figure in the first millennium AD [1].

By the late spring of 452, Attila had gathered capable troops and went ahead with launching a new campaign to make an incursion into Italy, the heart of the Roman Empire [2, p. 12].

By the middle of the 5th century, relations between the Western Roman Empire and the Hunnish Empire had deteriorated considerably. It became obvious that these forces were on the brink of a great confrontation. The events that took place in the mid-5th century provide evidence of the military might of the Hunnish Empire [3, p. 57].

Let us get down to the sources. We find evidences in the works of the early medieval authors, in particular, in the works of Jordanes, a Gothic historian of the $6^{\text {th }}$ century. It should be noted that he was not accurate in the dating of Attila the Hun's Italian campaign. For instance, in his opinion, on the way back after the Battle of the Catalaunian Plains (the year 453) Attila went to northern Italy to press the Romans [4]. As we can see, he mistook the events of 451 for those of 452. Chronicler Prosper Tiro, who witnessed the Huns' war in northern Italy, in his chronicles reflecting the events up to 455 wrote that Attila's Italian campaign was launched from Pannonia in 452. "Attila redintegrates viribus, quas in Gallia amiserat, Italiara ingredi per Pannonias intendit, nihil duce nostro Aetio secundum prioris belli opera prospiciente, ita ut ne clusuris quidem Alpiuin, quibus hostes prohiberi poterant, uteretur, hoc solum spebus suis superesse existimans, si ab omni Italia cum imperalore discederet, Sed cum hoc plenum dedecoris et periculi videretur, continuit verecundia metum..." (After Attila had incurred losses in his war in Gaul, he decided to go from Pannonia to Italy. At the same time, our general Aetius, who failed to show himself properly in the face of a looming war - he did nothing to hamper the Huns' passing through the Alpine gorges. He must have cherished the only hope - to escape from Italy together with the Emperor. But since it could have turned into indelible disgrace, he experienced both a sense of shame and fear ....). /5/

The defense of Aquileia, which was situated on the northern coast of the Adriatic Sea westward of Trieste and enumerated the 9th most important city in the Empire, held a special place in the course of the campaign.

According to Jordanes, the Huns' first move was the siege of Aquileia, the metropolis of Venetia, which is situated on a point or tongue of land by the Adriatic Sea. On the eastern side its walls are washed by the river Natissa, flowing from Mount Piccis. The siege was long and fierce, but Attila was able to do next to none, since the bravest soldiers of the Romans withstood him from within and his army was discontented and eager to withdraw. Attila chanced to be walking around the walls, considering whether to break camp or delay longer, and noticed that the white birds, namely, the storks, who build their nests in the gables of houses, were bearing their young from the city and, contrary to their custom, were carrying them out into the country. Being a shrewd observer of events, he understood this and said to his soldiers: "Look at these birds: foreseeing the future they are leaving the city sure to perish and are forsaking strongholds doomed to fall by reason of imminent peril. Do not think this a meaningless or uncertain sign; fear, arising from the things they foresee, has changed their custom." Why say more? He inflamed the hearts of his soldiers to attack Aquileia again. Having constructed battering rams and bringing to bear all manner of engines of war, they quickly forced their way into the city, laid it waste, divided the spoil and so cruelly devastated it as scarcely to leave a trace to be seen [4, pp. 219-222]. 
If we follow Jordanes, who referred to Priscus, the Huns captured Aquileia in late August or early September. We cite an important evidence of Pliny the Elder, who wrote that the storks left Italy after "Volcanalia", the main festival held in honour of Vulcanus, the Italic god of fire and smithcraft, which falls on August 23 [6]. And according to Paul the Deacon, the siege of Aquileia may have lasted for 3 months [7].

Thus, we are convinced once again and argue that Attila's Italian campaign was not launched immediately after the Battle of the Catalaunian Plains in the summer of 451, on the contrary, it was initiated as independent action in the spring of 452, and the Huns crossed the Julian Alps in May or June of 452.

In the collection of rare literary monuments of the famous library of Georg-August University of Göttingen that is well-known throughout Europe I (prof. K. Zhumagulov - author) found an interesting source that, at first glance, has nothing to do with the history of the Huns in Italy. It is a novella written by Valentinian III, the Roman Emperor, and dated June 29, 452 (Tit. XXXV. De suaris, boaris et pecuaris), telling about "drivers of swine, cows, sheep and goats." In the introductory part of the novella, the Emperor praises the patrician Aetius, who, under the conditions of war bewilderment, disorders and turmoil, found the time to see about supply of meat to the Holy City [8]. Indeed, this referred to the Huns' invasion in the end of June in 452, as there were no invasions from outside.

Now we hark back to Aquileia. The Huns took the rebellious city. Moreover, after a little while the city became the episcopal residence again, which is known to us from a letter sent by Pope Leo I to Bishop Nicetius (ad Nicetam episcopum Aquileiensem) on March 21, 458 [9]. The importance of the Christian community grew with further return of refugees. Soon the bishop of Aquileia became equal in rank to the bishops of Milan and Ravenna. And by the middle $6^{\text {th }}$ century Aquileia had been rebuilt; the ring of defensive walls and separate towers had been erected. Only the Lombards' invasion in 568 led to the complete destruction and fall of the city.

After taking Aquileia almost the entire northern Italy, the entire peninsula was opened to Attila. Hun armies captured Concordia, Altinum, Patavium /current Padova/, Vicentia /current Vicenza/, Verona, Brexia /current Brescia/, Bergamus (Bergamo), Milan (Mediolanum, Mailand), Ticinum /current Pavia/. $[2, \mathrm{p}, 12]$. Captured by the Huns, such large cities as Milan and Ticinum were not greatly ruined. Attila placed his residence in the Imperial Palace in Milan. There is a story has it that on entering the Palace Attila was surprised to see a wall-painting portraying both Eastern Roman Emperor and Western Roman Emperor (probably Theodosius II and Valentinian III), sitting on a golden throne and the Scythians were at their feet. The Scythians (Skythen) in the painting were the Huns (Hunni), since the authors of Late Antiquity, the early Middle Ages, or Byzantine ones such as Orosius, Priscus of Panium, Jordanes and others often called them so. As the story goes, Attila ordered to change the painting in such a way that it was he who sat enthroned, and both the Roman Emperors were pouring gold out of a bag to his feet [10].

Now, after the whole northern Italy had been conquered by the Huns, it was easy for them to reach Rome within a short time. It was becoming more and more apparent that the Empire did not have a force capable of stopping the onslaught of menacing invaders and Attila was close to world domination. The Hunnish Empire, consisting of four parts, stretched from the so-called Scythia (the kingdom of the Huns) to Germany (Scythica et Germanica regna) on its northern borders. Both the Eastern Roman Empire and Western Roman Empire were tributaries of Attila in the south. Incidentally, this was also confirmed by Jordanes in the following contexts containing dirges and epicedia, which commemorated the great deeds of the ruler (see below) [4, p. 257]. Thereby, Attila's Empire, occupying a vast territory and having great influence, geographically covered almost all the four parts of the world: from east to west and from north to south, which could be graphically demonstrated by the following scheme:

\begin{tabular}{|c|c|c|}
\hline $\begin{array}{l}\text { Germany } \\
\text { (Kingdoms of Germany) }\end{array}$ & North $(\mathrm{N})$ & $\begin{array}{l}\text { Scythia } \\
\text { (Kindom of the Huns) }\end{array}$ \\
\hline West (W) & & East $(\mathrm{O})$ \\
\hline Western Roman Empire & & Eastern Roman Empire \\
\hline
\end{tabular}

However, the Huns could not stay in Milan for a long time, since they did not have enough food for themselves and fodder for their horses. Sometimes they had to get the supplies from under the ruins. According to Hydatius (Idacius), a Spanish chronicler of the $5^{\text {th }}$ century, illness, hit the Huns "from heaven", turned the scales (... divinitus partim famae partim morbo quodam plagis caelestibus feriuntur ...) [11]. Undoubtedly, Prosper Tiro, being a contemporary Attila the Hun's Invasion of Italy, knew of the epidemic which raged among the Huns well, but according to him, the merit of having rescued Italy 
belonged exclusively to the Patriarch of Rome. Indeed, Northern Italy became to the Huns what about half a century earlier it had been to Alaric's Visigoths "regio funesta Getis", so to say, a land of death of the Goths, where the epidemic broke out. According to Claudius Claudian, "the epidemic was brought by foul food and aggravated by summer heat." ("Et taetris collecta cibis annique vapore. Saeviat aucta lues et milia proba superbus") [12].

But back to the dramatic events in Italy, where Attila and his victorious army were staying. This situation was difficult for the Western Roman Empire, but Valentinian III was in Ravenna, sitting out and anxiously watching the development of affairs. As for the commander Aetius, he was also confused. The army of Rome could not resist the onslaught of the Huns any more; it was paralyzed by their successes in Northern Italy. In the end, it was decided to use the way well-proven by the Eastern Romanians: they delegated an embassy to the court of Attila. It was headed by Pope St. Leo I, who was named the Great later on; Consul Gennadius Avienus and urban prefect of Rome Trygetius participated in the mission too. The contemporary of those days Prosper Tiro wrote, "...et tot nobilium provinciarum lattissima eversione credita est saevilia et cupiditas hostilis explenda, mhilque inter omnia consilia principis ac senatns populique Romani salubrius visum est, quam ut per legates pax truculentissimi regis expeteretur, Suscepit hoc negotim cum vim consulari Avieno et viro praefectorio Trygetio beatissimus papa Leo auxilio dei fretus, quem scirel numquam piorum laboribus defuisse. nee aliud secutum est quam praesumpserat fides, nam tota leganione dignanter accepts ita summi sacerdotis praesentia rex gavisus est, ut bello abstinerc praeciperet et ultra Danuvium promissa pace discederet" (and severe damage to a number of provinces, accompanied by cruelty and greed of the enemy left the only hope that the government, the Senate and the Roman people would find it the best way out to sue the ruthless king for peace via an embassy. Relying on the help of God, who, he knew, never failed in works of piety, the most blessed Pope Leo undertook these negotiations together with the ex-consul Avienus and the ex-prefect Trygetius. Nor did it turn out otherwise than faith had expected. The king received the whole delegation courteously, and he was so flattered by the presence of the highest priest that he ordered his men to stop the hostilities and, promising peace, returned beyond the Danube [5, $\mathrm{p}$. 482].

According to Jordan the meeting took place in the Ambulei Field, in the middle course of the Mincio River. At first glance, the meeting of two persons seems to be paradoxical. On the one hand, Attila, the ruler of the Hunnish Empire, a formidable conqueror; a man deeply absorbed the pagan ideas of his people. His name roused the pagandom of East and Northern Europe again at the time of the beginning of Christianity. On the other hand, Pope Leo I, the head of the Christian church hierarchy, a strict religionist.

Analyzing the rare sources available in the archives and collections in Europe, we do not find the detailed description of the mission to the court of Attila made by Leo I, which, incidentally, raised the authority and the prestige of the Pope objectively high, because he was able to influence the ruler of the peoples of East and West in such formidable for the Roman Empire hour. The meeting of the Pontiff, who represented a blessed one, and the ruler of the Hunnish Empire, who was nicknamed "flagellum dei", i.e., in verbatim translation from the Latin, "Scourge of God", was embellished with legends in writings as early as that time.

Here, we should direct attention to the nickname because it has been part of King of the Kings Attila's "calling card" in some or other publications so far, i.e. for one and half thousand years.

The nickname "flagellum dei", and it must be emphasized, was, so to speak, "the Church's view on the image of Attila." It follows from facts and is consistent; moreover, it is susceptible of proof if one wants to evolute the actual meaning of the word (the "Scourge of God").

Thus, according to the legend of Lupus dated the $5^{\text {th }}$ century, being asked by Lupus of Troyes, the Bishop of Gaul, "Who is there?", Attila might have answered: "I am Scourge of God" ("flagellum dei"), and the Bishop's words were as follows: "I am a servant of God, who expects his Lord's scourge".

Paul the Deacon, citing the legend of St. Leo the Great, wrote about a "venerable elder", who was standing next to the Pope and drawing on Attila the Hun with a naked sword [7. P. 12,14]. According to the legend, "The Holy Apostles Peter and Paul were close to the Pope, and, seeing them, Attila shuddered and came back"[13]. There are other legends, in which SS. Annianus of Orleans, Genevieve (Genovea) of Paris, John (Johannes) of Ravenna are holders of faith and order of God, and to whom Attila the Hun, a formidable conqueror, is portrayed as "the personification of evil world" [14]. It should be noted that legends represent the image of Attila in the Latin Church's point of view. Through the spectacle of Christian, the King of the Huns is seen as "Scourge of God," "infidel Attila," "evil demon", "foe of God", the Antichrist, the devil destroyer of order who is near a servant of God represented in the images of SS. Lupus, Annianus, Genevieve and others. 
The Latin historiography thereby ranges Attila, a heathen and "destroyer", against the Christian Roman Empire and the patrician Aetius, who is portrayed as its defender in the chronicles. It was he who led Visigoths, Burgundians, Franks and other Germanic nations, who had already adopted Christianity (if not Orthodox, but in the form of Arianism), not to mention the Gallo-Roman and Spanish-Roman population, who had acknowledged Christ long since), forgetting past differences and conflicts, in the hour of trial, when the Huns invaded in Gaul in 451. In his "History of the Goths", between 624 and 636, Isidore, the Bishop of Seville (570-636), wrote about Attila and the Huns as about "virga furoris dei sunt" [15], coincided in the meaning with "flagellum dei".

Thus, we have found out the time of occurrence of the nickname "flagellum dei" ("Scourge of God") and its actual original meaning, which primarily lay in the religious confrontation between Christianity and paganism. And it has a completely different hue in the image of Attila, who is still seen as the embodiment of evil, a bloodthirsty and cruel tyrant, etc. due to his nickname "Scourge of God". But let us return to the momentous meeting of $452 \mathrm{AD}$. Reading the papal correspondence of those years, we came across a letter of 512 or 513, which the bishops of the eastern regions addressed to Pope Symmachus (498-514). Its content allows us to learn that Pope St Leo I also spoke with Attila about the releasing the prisoners who had been captured by the Huns [16]ю

Continuing the analysis of the meeting of Attila and Pope St. Leo I on the Ager Ambuleius, we should note that the authority of the church and the papacy began rising straight after it [17].

Having returned to Pannonia, the ruler of Hunnish Empire started preparing a new military campaign, but now against the Eastern Roman Empire. According to Jordanes, "Attila returned to his encampment, and as if he had been bored with idlesse and felt sheathing the sword, he sent ambassadors to Marcian, the Emperor of the Eastern Empire, stating his intention to rob the provinces, because he was not paid tribute promised by Theodosius, the last Emperor of both the eastern and western halves of the Roman Empire, at all... (Reversus itaque Attila in sedes suas, et quasi otii penitens graviterque ferens a bello cessare, ad Orientis principem Marcianum legatos dirigit, provinciarum testans vastationem, quod sibi promissum Theodosio quondam imperatore minime persolveretur ...) [4. P. 225].

The King of the Huns spent the last months of his life preparing a campaign against the East. But a new war on the Byzantine Empire was not destined to break out. In the spring of $453 \mathrm{AD}$, Attila, the ruler of the Hunnic Empire, died.

\section{Conclusion}

Thus, we have analyzed the events of $451-452$ AD. Both European wars waged by the Huns evidence the military power of the Hunnic Empire. If in 451, the Western Roman Empire united almost the whole of the West against the Huns, then a few months later (less than a year) it could not resist their invasion into the heart of the Empire. The fact that the ruler of the huge state of the Huns who had both the Roman Empires as tributaries stopped before the city of Rome, because he had listened to requests of the embassy headed by the Pope, speaks for Attila's wisdom. He stopped the rampage of his troops, refusing from senseless destruction and sacrifices. Here Attila is compared favourably with Geiserich, the king of the Vandals or Alaric the Visigoth, despite the fact that the King of the Huns was nicknamed "Scourge of God", the destroyer of world order.

The Hunnish invasions of the middle of the fifth century - 451-452 AD objectively undermined the Western Roman Empire all the more, bringing its decline. It was going to happen very soon, namely in 476 AD, when Romulus Augustulus, the last Western Roman Emperor, was deposed by Odoacer, the leader of German mercenaries and the son of Edeko (Edikon), which at one time held a high position under Attila.

After Attila's death, the Hun Empire collapsed in the West during the reign of his sons. Some of the Huns stayed in the area northward of the Lower Danube. However, most of them went to the Greater Black Sea area and farther to the east, towards the Urals and the Aral Sea, i.e. to the fontal eastern limits of the huge Hunnic Empire. The local Huns continued marching on the neighbouring countries. So, the Huns-Ephtalits subjugated Gandhara at the end of the fifth century after a successful struggle against the Sassanids. Their leaders Toramana and Mihirakula captured the Gupta Empire in India in the first quarter of the sixth century. Armenian chronicles tell, for example, about the Huns' lands in the Northern Caucasus in the $7^{\text {th }}$ century. 
Список использованных литературы:

1. Жумагулов К. Т., Садыкова Р. О. Проблемы изучения истории гуннов и Евразии в связи со всемирной историей // Азиатская сочиальная наука. Том 11, № 19; 2015. - C. 309. URL: http://dx.doi.org/10.5539/ass.v11n19p306

2. Жумагулов К. Т., Садыкова Р. О. Аттила - гунн и перелом в древней истории. 3-я Международная междисциплинарная научная конференция по социальным наукам и искусствам SGEM 2016, Болгария, 2016, №1, с. 9-15.

3. Жумагулов К. Т., Садыкова Р. О. Поход Аттиль против Галлии и его значение //Абай атындагы Қазақ ұлттық педагогикалық университеті. Хабаршы. 2018. №3 (58), с. 56-61

4. Иорданес. Гетика, 219 -Monumenta Germaniae Historica. Auctores Antiquissimi. Под peд. T. М. Моммзена, Беролини, 1882, Т. В., п. И. Перевод на русский язык. - Увидимся с Джорданесом. Происхождение и деяния готов. М., 1960.

5. Проспер Тиро - уроженеи Аквитании, был секретарем папы Льва Великого. Проспер Tupo. Epitoma de Chronkon, 1367 - In: Monumenta Germaniae historica, Auctores Antiquissimi, T. IX, Chronica minora, Vol I. Ed. T. Mommsen, Berolini, 1892, p. 482.

6. Плиний Секунд. Naturaiis Historia, XVIII, 314.

7. Данные Павла Диакона, историка Лангобардов (около 720-800 г2.), должны быть автоматически исправлены, соответственно, и должны быть приняты как "3 месяиа" вместо “3 лет” (Павел Диакон. Historia Romana libri XVI. Под ред. Х. Дровсена - MGff, Аисt. Антиквариат. Беролини, 1879, Т. II, ХIV, 9; Ср. в этой связи: Сигоноа.. Де оксиденталь! империо. Майюнд, 1732, S. 498.).

8. Liber legum Novellarum D. Valentiniani III,- In: Novelae constitutiones imperatorum Theodosii II, Valentiniani III, Maximi, Maioriani, Severi, Anthemii. Под ред. Г. Хенеля Липсиенсиса, 1844 , c. $259-260$

9. Лео Магнус. Epistola CLIX, 21 Martii an 458.- In: Patrologia Latina. Ред. Ж.-П. Минь, Париж, 1865, Т. 54, c. 1135-1136.

10. Адтер A. (ffrsg.) Suidae Lexikon unter dein Сусло "Копукос". Лейпџиг, 1938, 3161 346; Cp. Ulrich-Bansa O. Moneta Mediolanensis. Venedig, 1949, S. 228, Anm.22

11. Hydatius Lemicius, Continuaiio chronicorum Hieronymianorum ad a. CCCCLXVIII'In: UGH, Auctores Antiquissimi, T. XI. Chronica Minora, vol. II Изд./ T. Моммзен, Бемлим, 1894, 26, 154.

12. Клавдий Клавдиани кармина 28 (panagyricus de VI consulatu Honorii Augusti, 274, 241 242. In: MGH. Ayкm. Antiquissimi, T. X, Berolini, 1892; cp. Ambrosius St. Epistota XV, an. 383--: Patrologia Latina. Ed, J.-P, Migne, Paris, 1866, T. 16, p 998.

13. Лео Магнус. Проповеди. - In: Patrologia Latina. Ed.J.-P. Migne. T. 54, 1865, p.433-434.

14. Vita St. Genovefae. Под ред. К. Кунсиле. Лейпииг, 1910; См. Жумагулов К. Т. Галльские походы Аттиль. Стр. 133-134.

15. Isidorus Hispalensis. Historia Gothorum. - MGH, Auct, Antiq. T. XI. Chronica minora, saec. V - VII. Ред. T. Моммзен, Беролини, Вайдманнос, 1894. T. 2. С. 279.

16. Patrologia Latina, c. 59-60; Cp. Caspar E. Geschichte des Papsttums. Bd. II. Тюбинген, 1933. 121-122.

17. Ниебур Р. Глаубе и Гешихте (вера и история), дойч фон Д. Шмидт. Mbnchen, P. Müller, 1951.

[17a] Жумагулов К. Т., Садыкова Р. О. Актуальные вопросы исследования и преподавания истории гуннов. Procedia - Социальные и поведенческие науки. 2-я Кипрская международная конференция по образовательным исследованиям. - 2013. - Том 89. - С. 308-311. 


\section{References:}

1. Zhumagulov K.T., Sadykova R.O. Problems in the Study of the Huns and Eurasian history in Relation to world History // Asian Social Science. Vol. 11, No. 19; 2015. - P.309. URL: http://dx.doi.org/10.5539/ass.v11n19p306

2. Zhumagulov K.T., Sadykova R.O. Attila the Hun and the turning point of ancient history. 3 rd International Multidisciplinary Scientific conference on Social sciences and arts SGEM 2016, Bulgary, 2016, №1, pp. 9-15.

3. Zhumagulov K.T., Sadykova R.O. Attila's campaign against Gaul and its importance //Aбaŭ атындавы Қазақ ұлттық педагогикалық университеті. Хабаршы. 2018. №3 (58), с. 56-61

4. Jordanes. Getica, 219 -Monumenta Germaniae Historica. Auctores Antiquissimi. Ed. Th. Mommsen, Berolini, 1882, T. V, p. I. Translated into the Russian language. - See Jordanes. The origin and deeds of the Goths. M., 1960.

5. Prosper Tiro - a native of Aquitaine, was secretary of Pope Leo the Great. Prosper Tiro. Epitoma de Chronkon, 1367 - In: Monumenta Germaniae historica, Auctores Antiquissimi, T. IX, Chronica minora, Vol I. Ed. T. Mommsen, Berolini, 1892, p.482.

6. Plinius Secundus. Naturaiis Historia, XVIII, 314.

7. The data of the Paul the Deacon, the historian of the Lombards (around 720-800) must be automatically corrected, respectively, and should be taken as " 3 months" instead of "3 years" (Paulus Diaconus. Historia Romana libri XVI. Ed. H.Drovsen - MGff, Auct. Antiquiss. Berolini, 1879, T. II, XIV, 9; Ср.6 этой связи: Sigonoa C. De occidental! imperio. Maiiund, 1732, S. 498.).

8. Liber legum Novellarum D. Valentiniani III,- In: Novelae constitutiones imperatorum Theodosii II, Valentiniani III, Maximi, Maioriani, Severi, Anthemii. Ed. G.Haenel Lipsiensis, 1844, p. 259-260

9. Leo Magnus. Epistola CLIX, 21 Martii an 458.- In: Patrologia Latina. Ed. J.-P.Migne, Paris, 1865, T.54, p.1135-1136.

10. Adter A. (ffrsg.) Suidae Lexikon unter dein Wort "Kopukos". Leipzig, 1938, 3,161,346; Cp. Ulrich-Bansa O. Moneta Mediolanensis. Venedig, 1949, S. 228, Anm.22

11. Hydatius Lemicius, Continuaiio chronicorum Hieronymianorum ad a. CCCCLXVIII'In: UGH, Auctores Antiquissimi, T. XI. Chronica Minora, vol. II Ed/Th. Mommsen, Bemlim, 1894, 26, 154.

12. Claudii Claudiani carmina 28 (panagyricus de VI consulatu Honorii Augusti, 274, 241-242. In: MGH. Auct. Antiquissimi, T.X, Berolini, 1892; cp. Ambrosius St. Epistota XV, an. 383--: Patrologia Latina. Ed, J.-P, Migne, Paris, 1866, T. 16, p 998.

13. Leo Magnus. Sermones. - In: Patrologia Latina. Ed.J.-P. Migne. T.54, 1865, p.433-434.

14. Vita St.Genovefae. Ed. C.Kunsile. Leipzig, 1910; See Zhumagulov K.T. Attila's Gallic campaigns. Pp.133-134.

15. Isidorus Hispalensis. Historia Gothorum. - MGH, Auct, Antiq. T.XI. Chronica minora, saec. VVII. Ed. T. Mommsen, Berolini, Weidmannos, 1894. Vol. 2. P. 279.

16. Patrologia Latina, p. 59-60; Cp. Caspar E. Geschichte des Papsttums. Bd. II. Tübingen, 1933. 121-122.

17. Nieebur R. Glaube und Geschichte (Faith and history), deutsch von D.Schmidt. Mbnchen, P.Müller, 1951.

[17a] Zhumagulov K.T., Sadykova R.O. Actual Issues of Research and Teaching of Hun's History. Procedia - Social and Behavioral Sciences. $2^{\text {nd }}$ Cyprus International Conference on Educational Research. - 2013. - Volume 89. - P. 308-311. 